\title{
LESSON 58
}

Letter 29

PAPER: Suitable.

TARGET TIME: 15 minutes.

Take a carbon copy and address a sheet of $A 6$ paper as an envelope.

Tabulation 19

PAPER: A5.

TARGET TIME: 15 minutes.

Type the heading in spaced capitals (Lesson 40). Arrange the names in alphabetical order.

Letter 30

PAPER: Suitable.

TODAY'S DATE

TARGET TIME: 13 minutes.

Address a sheet of $A 6$ paper as an envelope.
Ref. JC/RB

To-day's date

The Suprex Manufacturing Co. Ltd., 23 City Road, Maidenhead. MA6 8LQ

Dear Sirs, Following tests on the samples of goods you sent to us for evaluation, we are prepared to place a trial order with you for the following goods:

$\begin{array}{rlr}10 & \text { Cases of Ready-Fix Plugs } & £ 15.00 \\ 25 & \text { Gallons Ready-Strip Paint Remover } & £ 100.00 \\ 120 & \text { Ready-Paint Brush Sets } & £ 240.60\end{array}$

The goods will be expected by the first of next month and we would remind you that you offered us a special discount of $25 \%$ on the first order placed.

Yours faithfully, J. Chattin Chief Buyer

$$
S \text { C H O O L C H E S S T E A M }
$$

\begin{tabular}{|l|l|}
\hline Fourth Year Boys & Fourth Year Girls \\
\hline S. James & S. Thomas \\
M. Smith & J. Onions \\
S. Dyke & G. Olly \\
G. Hall & S. Kaur \\
F. Bear & C. Gillman \\
K. Wright & L. Denning \\
P. Beddow & P. Bowden \\
R. Barker & J. Sutton \\
P. Rice & P. Taylor \\
\hline
\end{tabular}

Ref. HD/RC Robert Cotterile, Eog, 18 Coombe Houpe, Arboyne Aberdeenshice ABS2AW Dear Sir, Following our telephore conversation thes morning, 9 am enclosing a reel of Jess Roise Tape for waluation. (Paragraph) Unfortunataly 9 find we are, at the moment, out of stock of the particilar reel about which we spoke, and the tope \& 6 an sending is in fact slighty longen than the ore $\mathrm{F}$ aduised. However, lus spool sige do idestical in both cases, so bat you will stile be able to asass it usufulress for your partisclear apolication. (Paragrapl) I asoure you of Cour athition and service. Yours faitefly.

TAPE TECHNICAL SERUICES H.Duckhouse Sales Manager Ene. 